\title{
Single Nucleotide Polymorphisms in Selected Apoptotic Genes and BPDE-Induced Apoptotic Capacity in Apparently Normal Primary Lymphocytes: A Genotype-Phenotype Correlation Analysis
}

\author{
Zhibin Hu, ${ }^{1}$ Chunying Li, ${ }^{1}$ Kexin Chen, ${ }^{1}$ Li-E Wang, ${ }^{1}$ Erich M. Sturgis, ${ }^{1,2}$ Margaret R. Spitz, ${ }^{1}$ and Qingyi Wei ${ }^{1}$ \\ ${ }^{1}$ Department of Epidemiology, The University of Texas M. D. Anderson Cancer Center, Houston, TX 77030, USA \\ ${ }^{2}$ Department of Head and Neck Surgery, The University of Texas M. D. Anderson Cancer Center, Houston, TX 77030, USA \\ Correspondence should be addressed to Qingyi Wei, qwei@mdanderson.org
}

Received 31 December 2007; Accepted 23 August 2008

Recommended by Paolo Vineis

\begin{abstract}
Apoptotic capacity (AC) in primary lymphocytes may be a marker for cancer susceptibility, and functional single nucleotide polymorphisms (SNPs) in genes involved in apoptotic pathways may modulate cellular AC in response to DNA damage. To further examine the correlation between apoptotic genotypes and phenotype, we genotyped 14 published SNPs in 11 apoptosis-related genes (i.e., p53, Bcl-2, BAX, CASP9, DR4, Fas, FasL, CASP8, CASP10, CASP3, and CASP7) and assessed the AC in response to benzo[a]pyrene-7,8-9,10-diol epoxide (BPDE) in cultured primary lymphocytes from 172 cancer-free subjects. We found that among these 14 SNPs, R72P, intron 3 16-bp del/ins, and intron $6 \mathrm{G}>\mathrm{A}$ in $p 53,-938 \mathrm{C}>\mathrm{A}$ in $\mathrm{Bcl}-2$, and I522L in CASP10 were significant predictors of the BPDE-induced lymphocytic AC in single-locus analysis. In the combined analysis of the three $p 53$ variants, we found that the individuals with the diplotypes carrying 0-1 copy of the common $p 53$ R-del-G haplotype had higher AC values compared to other genotypes. Although the study size may not have the statistical power to detect the role of other SNPs in AC, our findings suggest that some SNPs in genes involved in the intrinsic apoptotic pathway may modulate lymphocytic AC in response to BPDE exposure in the general population. Larger studies are needed to validate these findings for further studying individual susceptibility to cancer and other apoptosis-related diseases.
\end{abstract}

Copyright (c) 2008 Zhibin Hu et al. This is an open access article distributed under the Creative Commons Attribution License, which permits unrestricted use, distribution, and reproduction in any medium, provided the original work is properly cited.

\section{INTRODUCTION}

Apoptosis, also known as the programmed cell death, is a biological process that regulates physiological cell death and plays an important role in the pathogenesis of a variety of human diseases, including cancer [1]. Resistance to apoptosis or reduced cellular apoptotic capacity (AC) provides a survival advantage of the cells that may develop into cancer cells, commonly seen in almost all types of malignant diseases, and mutations in the genes involved in apoptotic pathways are one of the molecular mechanisms underlying carcinogenesis $[2,3]$ and cancer therapy $[3,4]$.

Benzo[a]pyrene $(\mathrm{B}[\mathrm{a}] \mathrm{P})$ is a classic DNA-damaging carcinogen found in both tobacco smoke and the environment as a result of fuel combustion [5]. Its bioactivated form, benzo[a]pyrene diol epoxide (BPDE), can cause irreversible damage to DNA by forming DNA adducts through covalent binding or oxidation $[6,7]$. If these adducts are unrepaired, the cells will undergo apoptosis through activation of $\mathrm{p} 53$, caspase-9 (CASP9), and caspase-3 (CASP3) $[8,9]$. As a pivotal regulator of cellular response to DNA damage, the transcription factor encoded by the $p 53$ tumor suppressor gene has been clearly implicated in B[a]P-induced apoptosis, and the levels of $\mathrm{p} 53$ protein expression has been correlated with the levels of $\mathrm{B}[\mathrm{a}] \mathrm{P}-\mathrm{DNA}$ adducts $[8,10]$. Although details of the signaling pathways that trigger apoptosis in lymphocytes remain not fully understood, possible mechanisms include transcriptional activation of the $\mathrm{Bcl}-2$ family members [11] and transcriptional upregulation of the death receptors (DRs) $[12,13]$. These complex proteins participate in the activation of a sequential signaling that modulates two main apoptotic pathways [4]. One is the intrinsic or mitochondrial pathway, in which the stimuli of p53-Bcl2 pathway lead to the activation of CASP9 and release 
of cytochrome c from the mitochondria [14]. The other, referred to as the extrinsicor cytoplasmic pathway, involves a group of proteins such as the DRs, the membrane-bound Fas ligand, the Fas complexes, the Fas-associated death domain, caspase-8 (CASP8), and caspase-10 (CASP10) [15, 16]. Activation of these two pathways initiates a common downstream proteolytic cascade that involves CASP3 and caspase-7 (CASP7) [4].

It is likely that the efficiency of these apoptotic pathways is genetically determined. Therefore, we hypothesized that functional polymorphisms in genes involved in these apoptotic pathways may modulate the AC phenotype, thus contributing to individual variation in response to DNA damage. To test this hypothesis, we selected 14 potentially functional polymorphisms in 11 genes, that is, p53, Bcl-2, $B A X$, and CASP9 involved in the intrinsic pathway; DR4, Fas, FasL, CASP8, and CASP10 involved in the extrinsic pathway; and CASP3 and CASP7, the effective CASPs. We genotyped for these 14 polymorphisms and assessed in vitro AC with a terminal deoxynucleotidyl transferase-mediated dUTPbiotin nick-end labeling (TUNEL) assay using BPDE-treated primary lymphocytes from 172 subjects without cancer to evaluate associations between their apoptotic genotypes and the AC phenotype.

\section{MATERIALS AND METHODS}

\subsection{Study population}

Subjects in the current study were the control subjects in a molecular epidemiology study of lung cancer previously described [17]. Briefly, 172 subjects in this study were randomly selected from a pool of cancer-free control subjects recruited from the Kelsey-Seybold Clinics, a large multispecialty physician organization with several clinics throughout the Houston metropolitan area. Each subject was scheduled to be interviewed after a written informed consent was obtained. After the interview, a venous blood sample of about $20 \mathrm{~mL}$ was collected from each subject. The research protocol was approved by The University of Texas M. D. Anderson Cancer Center and the Kelsey-Seybold Foundation institutional review boards.

\subsection{SNP selection}

We used the National Center for Biotechnology Information (NCBI) dbSNP database (http://www.ncbi.nlm.nih.gov), the National Institute of Environmental Health Sciences (NIEHS) Environment Genome Project SNP databases (http://egp.gs.washington.edu/directory.html and http:// www.genome.utah.edu/genesnps/) and literature search to identify potentially functional variants in genes involved in both intrinsic and extrinsic apoptotic pathways. Polymorphisms with a minor allele frequency (MAF) of $\geq 0.05$ were included, if they may theoretically result in amino acid changes (nonsynonymous SNP, nsSNP), located at regulating regions such as promoters, or are reportedly associated with known phenotypic effects. Three reported p53 SNPs were selected, including the well-known codon 72
SNP (R72P, G > C) and two intronic variants (a $16 \mathrm{bp}$-del/ins in intron 3 and a G-to-A transition in intron 6 because their haplotypes were found to be functional [18]. Two previously reported regulating SNPs in the promoters of the Bcl-2 family members, $B c l-2(-938 \mathrm{C}>\mathrm{A})$ and $B A X$ $(-248 \mathrm{G}>\mathrm{A})[19,20]$, were included. For the CASPs, we identified one nsSNP from each CASP8 (D302H, G $>C$ ), CASP10 (I522L, A > T) [21], and CASP7 (D255E, C $>$ G, http://www.ncbi.nlm.nih.gov) and one of the two CASP9 nsSNPs in tight linkage disequilibrium (LD) (Q221R, G > A, http://egp.gs.washington.edu/directory.html and [22]. Because no nsSNP was found in the coding region of CASP3, we selected one common variant in its promoter region: $-1337 \mathrm{C}>\mathrm{G}$ (http://www.genome.utah.edu/genesnps/). For the death receptor genes, one nsSNP in DR4 and three promoter SNPs in Fas and FasL were selected: T209R (C > G) in $D R 4,-1377 \mathrm{G}>\mathrm{A}$ and $-670 \mathrm{~A}>\mathrm{G}$ in Fas, and $-844 \mathrm{~T}>\mathrm{C}$ in FasL [23-26].

\subsection{Genotyping}

The genotyping methods used to distinguish the 14 selected polymorphisms in 11 apoptosis-related genes are presented in Table 1. Genotyping methods for seven of the polymorphisms were previously described: p53 R72P [27]), p53 intron 3 16-bpdel/ins and intron $6 \mathrm{G}>\mathrm{A}$ [18], DR4 T209R [28], Fas -1377G $>$ A and -670A > G [29], and FasL $844 \mathrm{~T}>\mathrm{C}[30]$. The remaining seven polymorphisms (i.e., $\mathrm{Bcl}$ 2 -938C >A, BAX -248G >A, CASP9 Q221R, CASP8 D302H, CASP10 I522L, CASP3 -1337C > G, and CASP7 D255E) were detected by using a primer-introduced restriction analysis (PIRA) - polymerase chain reaction (PCR) assay [31] and summarized in Table 1. Genotyping was performed without knowledge of the subjects' phenotype; more than $10 \%$ of the samples were randomly selected for confirmation, and the results were $100 \%$ concordant. For the seven self-designed genotyping assays, PCR products containing each target genotype were purified and the sequences were confirmed by direct sequencing.

\subsection{Apoptosis assay}

The apoptosis phenotype (i.e., apoptotic capacity [AC]) was detected with the TUNEL assay previously described [32]. Briefly, two parallel short-term cultures from each blood sample were incubated at $37^{\circ} \mathrm{C}$ without $\mathrm{CO}_{2}$ for 67 hours before BPDE treatment. At the end of the incubation, one of the two parallel cultures was treated with BPDE (98\% pure; Midwest Research Institute, Kansas City, Mo, USA) at a final concentration of $4 \mu \mathrm{M}$. After an additional 5hour incubation, all cells were pelleted by centrifugation, resuspended with lysis buffer (Human Erythrocyte Lysing Kit, R\&D Systems, Minneapolis, Minn, USA), fixed for 1 hour, rinsed with phosphate-buffered saline, and finally stored in $70 \%$ ethanol at $-20^{\circ} \mathrm{C}$ until used for the TUNEL assay.

For the TUNEL assay, we used the APO-BRDU kit (Phoenix Flow Systems, San Diego, Calif, USA) and followed the manufacturer's recommended protocol. The ratio of the 
TABLE 1: Conditions of genotyping assays for the selected polymorphisms of some apoptotic genes.

\begin{tabular}{|c|c|c|c|c|c|c|}
\hline Gene & $\begin{array}{l}\text { Position, } \\
\text { base change, } \\
\text { and rs\# }\end{array}$ & $\begin{array}{l}\text { Genotyping } \\
\text { method }^{(\mathrm{a})}\end{array}$ & Primer & $\begin{array}{l}\text { PCR } \\
\text { product }\end{array}$ & Enzyme & Gel band pattern \\
\hline p53 & $\begin{array}{l}\text { R72P G>C } \\
\text { rs } 1042522\end{array}$ & PCR-RFLP & $\begin{array}{l}\text { 5'-ATCTACAGTCCCCCTTGCCG-3' (sense) } \\
5^{\prime} \text {-GCAACTGACCGTGCAAGTCA-3' (antisense) }\end{array}$ & $296 \mathrm{bp}$ & $B s t U \mathrm{I}$ & $\begin{array}{l}\text { G allele: } 169 \text { bp, } \\
127 \text { bp } \\
\text { C allele: } 296 \text { bp }\end{array}$ \\
\hline p53 & $\begin{array}{l}\text { Intron } 3 \\
\text { 16-bpins/del } \\
\text { rs } 17878362\end{array}$ & PCR & $\begin{array}{l}5^{\prime} \text {-TGGGACTGACTTTCTGCTCTT-3' (sense) } \\
5^{\prime} \text {-TCAAATCATCCATTGCTTGG-3' (antisense) }\end{array}$ & & & $\begin{array}{l}\text { Del: } 180 \text { bp } \\
\text { Ins: } 196 \text { bp }\end{array}$ \\
\hline p53 & $\begin{array}{l}\text { Intron } 6 \\
\mathrm{G}>\mathrm{A} \\
\text { rs1625895 }\end{array}$ & PCR-RFLP & $\begin{array}{l}\text { 5'-TGGCCATCTACAAGCAGTCA-3' (sense) } \\
5^{\prime} \text {-TTGCACATCTCATGGGGTTA-3' (antisense) }\end{array}$ & $404 \mathrm{bp}$ & MspI & $\begin{array}{l}\text { G allele: } 336 \text { bp, } \\
68 \text { bp } \\
\text { A allele: } 404 \text { bp }\end{array}$ \\
\hline$B c l-2$ & $\begin{array}{l}-938 \mathrm{C}>\mathrm{A} \\
\mathrm{rs} 2279115\end{array}$ & $\begin{array}{l}\text { PIRA-PCR: } \\
\text { mismatch, antisense } \\
\text { primer +2 C-to-G }\end{array}$ & $\begin{array}{l}\text { 5'-TCCTGCCTTCATTTATCCAGCA-3' (sense) } \\
5^{\prime} \text {-CCAGGAGAGAGACAGGGGACA-3' (antisense) }\end{array}$ & $125 \mathrm{bp}$ & NlaIII & $\begin{array}{l}\text { C allele: } 106 \mathrm{bp}, \\
19 \mathrm{bp} \\
\text { A allele: } 125 \mathrm{bp}\end{array}$ \\
\hline$B A X$ & $\begin{array}{l}-248 \mathrm{G}>\mathrm{A} \\
\mathrm{rs} 4645878\end{array}$ & $\begin{array}{l}\text { PIRA-PCR: } \\
\text { mismatch, sense } \\
\text { primer -2 G-to-C }\end{array}$ & $\begin{array}{l}\text { 5'-CATTAGAGCTGCGATTGGACCG-3' (sense) } \\
5^{\prime} \text {-GCTCCCTCGGGAGGTTTGGT-3' (antisense) }\end{array}$ & $109 \mathrm{bp}$ & MspI & $\begin{array}{l}\text { G allele: } 89 \mathrm{bp}, \\
20 \mathrm{bp} \\
\text { A allele: } 109 \mathrm{bp}\end{array}$ \\
\hline CASP9 & $\begin{array}{l}\text { Q221R G>A } \\
\text { rs } 1052576\end{array}$ & $\begin{array}{l}\text { PIRA-PCR: } \\
\text { mismatch, sense } \\
\text { primer-2 G-to-C }\end{array}$ & $\begin{array}{l}5^{\prime} \text {-GGCTTTGCTGGAGCTGGCCC-3' (sense) } \\
5^{\prime} \text {-AGTACCCAATGCCTGCCCAGGG-3' (antisense) }\end{array}$ & $121 \mathrm{bp}$ & MspI & $\begin{array}{l}\text { G allele: } 102 \text { bp, } \\
19 \text { bp } \\
\text { A allele: } 121 \text { bp }\end{array}$ \\
\hline$D R 4$ & $\begin{array}{l}\text { T209R C > G } \\
\text { rs } 4871857\end{array}$ & PCR-RFLP & $\begin{array}{l}5^{\prime} \text {-ATCCTCTGGGAACTCTGTGG-3' (sense) } \\
5^{\prime} \text {-GGGGACAGGCAGATGGAC-3' (antisense) }\end{array}$ & $300 \mathrm{bp}$ & DraIII & $\begin{array}{l}\text { C allele: } 200 \text { bp, } \\
100 \text { bp } \\
\text { G allele: } 300 \text { bp }\end{array}$ \\
\hline Fas & $\begin{array}{l}-1377 \mathrm{G}>\mathrm{A} \\
\mathrm{rs} 2234767\end{array}$ & $\begin{array}{l}\text { PIRA-PCR: } \\
\text { mismatch, sense } \\
\text { primer -2 A-to-G }\end{array}$ & $\begin{array}{l}\text { 5'-TGTGTGCACAAGGCTGGCGC-3' (sense) } \\
\text { 5' }^{\prime} \text {-TGCATCTGTCACTGCACTTACCACCA-3' } \\
\text { (antisense) }\end{array}$ & $122 \mathrm{bp}$ & $B s t U \mathrm{I}$ & $\begin{array}{l}\text { G allele: } 104 \mathrm{bp}, \\
18 \mathrm{bp} \\
\text { A allele: } 122 \mathrm{bp}\end{array}$ \\
\hline Fas & $\begin{array}{l}-670 A>G \\
\text { rs } 1800682\end{array}$ & PCR-RFLP & $\begin{array}{l}\text { 5'-ATAGCTGGGGCTATGCGATT-3' (sense) } \\
5^{\prime} \text {-CATTTGACTGGGCTGTCCAT-3' (antisense) }\end{array}$ & 193 bp & ScrFI & $\begin{array}{l}\text { A allele: } 193 \mathrm{bp} \\
\text { G allele: } 136 \mathrm{bp} \\
57 \mathrm{bp}\end{array}$ \\
\hline FasL & $\begin{array}{l}-844 \mathrm{~T}>\mathrm{C} \\
\mathrm{rs} 763110\end{array}$ & $\begin{array}{l}\text { PIRA-PCR: } \\
\text { mismatch, sense } \\
\text { primer -7 A-to-C }\end{array}$ & $\begin{array}{l}5^{\prime} \text {-CAATGAAAATGAACACATTG-3' (sense) } \\
5^{\prime} \text {-CCCACTTTAGAAATTAGATC-3' (antisense) }\end{array}$ & 85 bp & DraIII & $\begin{array}{l}\text { T allele: } 66 \mathrm{bp} \\
19 \mathrm{bp} \\
\text { G allele: } 85 \mathrm{bp}\end{array}$ \\
\hline CASP8 & $\begin{array}{l}\text { D302H G }>C \\
\text { rs } 1045485\end{array}$ & $\begin{array}{l}\text { PIRA-PCR: } \\
\text { mismatch, sense } \\
\text { primer -2 A-to-G }\end{array}$ & $\begin{array}{l}5^{\prime} \text {-CATTTTGAGATCAAGCCCCGC-3' (sense) } \\
5^{\prime} \text {-CCCTTGTCTCCATGGGAGAGGA-3' (antisense) }\end{array}$ & $132 \mathrm{bp}$ & $B s t U \mathrm{I}$ & $\begin{array}{l}\text { G allele: } 112 \mathrm{bp}, \\
20 \mathrm{bp} \\
\text { C allele: } 132 \mathrm{bp}\end{array}$ \\
\hline CASP10 & $\begin{array}{l}\text { I522L A }>\text { T } \\
\text { rs } 13006529\end{array}$ & $\begin{array}{l}\text { PIRA-PCR: } \\
\text { mismatch, antisense } \\
\text { primer }+4 \text { A-to- } T\end{array}$ & $\begin{array}{l}\text { 5'-GAGTGGACAAACAGGGAACAAA-3' (sense) } \\
5^{\prime} \text {-AGAACCAACAAAAACTCTCTGCAATA-3' } \\
\text { (antisense) }\end{array}$ & $122 \mathrm{bp}$ & SspI & $\begin{array}{l}\text { T allele: } 97 \mathrm{bp}, \\
25 \mathrm{bp} \\
\text { A allele: } 122 \mathrm{bp}\end{array}$ \\
\hline CASP3 & $\begin{array}{l}-1337 \mathrm{C}>\mathrm{G} \\
\mathrm{rs} 1405937\end{array}$ & $\begin{array}{l}\text { PIRA-PCR: } \\
\text { mismatch, sense } \\
\text { primer -2 C-to-A }\end{array}$ & $\begin{array}{l}5^{\prime} \text {-ATAGGCGCAAGTGTTAGAAACAGGAT-3' (sense) } \\
5^{\prime} \text {-CACCAACACATGTGAGCACGAC-3' (antisense) }\end{array}$ & 112 bp & FokI & $\begin{array}{l}\text { C allele: } 112 \mathrm{bp} \\
\text { G allele: } 76 \mathrm{bp} \\
36 \mathrm{bp}\end{array}$ \\
\hline CASP7 & $\begin{array}{l}\mathrm{D} 255 \mathrm{E} C>\mathrm{G} \\
\mathrm{rs} 2227310\end{array}$ & $\begin{array}{l}\text { PIRA-PCR: } \\
\text { mismatch, sense } \\
\text { primer-2 G-to-C }\end{array}$ & $\begin{array}{l}5^{\prime} \text {-CCTGGAGGAGCACGGAAAACA-3' (sense) } \\
5^{\prime} \text {-TGGAGACCACACAGGGGATCTG-3' (antisense) }\end{array}$ & $137 \mathrm{bp}$ & $P v u \mathrm{II}$ & $\begin{array}{l}\text { G allele: } 115 \text { bp, } \\
22 \text { bp } \\
\text { C allele: } 137 \text { bp }\end{array}$ \\
\hline
\end{tabular}

${ }^{(a)}$ RFLP = restriction fragment length polymorphisme; PIRA = primer-introduced restriction analysis.

difference in the percentages of apoptotic cells in a subject's BPDE-treated and untreated cultures to the percentage of apoptotic cells in the untreated culture was recorded as the $\left.\mathrm{AC}\left(\mathrm{AC} \%=\left[\mathrm{AC}_{\text {treated }}-\mathrm{AC}_{\text {baseline }}\right) / \mathrm{AC}_{\text {baseline }}\right] \times 100\right)[32]$.

\subsection{Statistical analysis}

DNA quality or quantity was insufficient for genotyping in 2 subjects; thus, the final analysis included 170 persons. 
Differences of the continuous AC measurements between genotypes/diplotypes of apoptotic genes were evaluated by using Student's $t$-test. Trend test was performed by using the general linear regression model with adjustment for age and sex. We dichotomized the continuous phenotype measurements by using the median (150\%) as the cutoff value to obtain an almost equal low-AC subgroup (84 subjects) and high-AC subgroup (86 subjects). Logistic regression analyses were used to estimate theodds ratios (ORs) and 95\% confidence intervals (CIs) between combined genetic variants and dichotomized AC phenotype with adjustment for age and sex. Alleles/haplotypes associated with the lower AC phenotype in individual polymorphism analysis were termed as "at-risk" alleles hereinafter. We used the PHASE 2.0 program [33] to infer haplotype frequencies based on the observed genotypes for each gene. Diplotype was the most probable haplotype pair for each individual. The potential gene-gene interaction was evaluated by logistic regression analysis and tested by comparing the changes in deviance (2 log likelihood) between the models of main effects with or without the interaction term. All of the statistical analyses were performed with statistical analysis system software (v.9.1.3; SAS Institute, Inc., Cary, NC, USA).

\section{RESULTS}

The mean age $( \pm \mathrm{SD}$, years $)$ of the 170 study subjects (119 males and 51 females) was $57.99 \pm 12.10$, and we dichotomized age by using the cutoff value of 60 years to facilitate comparisons between age groups. No statistical difference was found in the continuous AC measurements between the subgroups according to age and sex (data not shown). Table 2 shows the continuous AC measurements by genotypes of the selected apoptotic genes. The observed genotype frequencies were all consistent with those expected from the Hardy-Weinberg equilibrium (data not shown). For SNPs in genes involved in the intrinsic apoptotic pathway, variant homozygotes of $p 53$ intron 316 -bpins/ins, $p 53$ intron $6 \mathrm{AA}$, and $\mathrm{Bcl}-2$-938AA all had significantly higher AC than their corresponding wild-type homozygotes $(496.07 \pm 121.26$ versus $204.22 \pm 183.21$ for $p 53$ intron 316 -bpdel/ins, $P=$ $.027 ; 496.07 \pm 121.26$ versus $199.44 \pm 179.10$ for $p 53$ intron $6 \mathrm{G}>\mathrm{A}, P=.021$, and $247.62 \pm 225.67$ versus $164.06 \pm 154.89$ for $\mathrm{Bcl}-2-938 \mathrm{C}>\mathrm{A}, P=.046)$. However, the significant $P$ values for the trend of higher $\mathrm{AC}$ with increasing number of the variant alleles were observed only for p53 R72P (.016) and $\mathrm{Bcl}-2-938 \mathrm{C}>\mathrm{A}(.037)$ as assessed in the general linear regression model with adjustment for age and sex (Table 2). In contrast, only the variant homozygotes of CASP10 I522L out of all SNPs in genes involved in the extrinsic apoptotic pathway had significantly lower AC $(159.49 \pm 171.44)$ than the II homozygote $(239.07 \pm 205.18, P=.046)$ as well as a significant trend of lower AC with increasing number of the variant alleles $(P=.046)$.

Linkage disequilibrium (LD) analysis showed that the three loci in $p 53$ were in $\mathrm{LD}\left(r^{2}=0.14, D^{\prime}=0.64\right.$ for R72P and intron 3 16-bpdel/ins; $r^{2}=0.24, D^{\prime}=0.85$ for R72P and intron $6 \mathrm{G}>\mathrm{A}$; and $r^{2}=0.60, D^{\prime}=0.79$ for intron 3 16-bpdel/ins and intron $6 \mathrm{G}>\mathrm{A}$ ). Therefore, we performed haplotype/diplotype inference using the PHASE 2.0 program based on the observed genotypes. Overall, three common hapolotypes were derived (Table 3 ). The diplotype carrying zero copy of the $p 53 \mathrm{R}$-del-G haplotype and the diplotype carrying two copies of the p53 P-ins-A haplotype all had significantly higher AC (termed as "protective" hereinafter) and the effect of the R-del-G haplotype was in a doseresponse manner ( $P$ for trend: .016; Table 3 ).

\section{DISCUSSION}

In the genotype-phenotype analysis, we examined the role of potentially functional variants in selected apoptotic genes in the AC phenotype induced by BPDE treatment in primary lymphocytes. We found that $\mathrm{R} 72 \mathrm{P}$, intron 3 16-bpdel/ins, intron $6 \mathrm{G}>\mathrm{A}$ in $\mathrm{p53},-938 \mathrm{C}>\mathrm{A}$ in $\mathrm{Bcl}-2$, and $1522 \mathrm{~L}$ in CASP10 may be predictors of $\mathrm{AC}$, but the effects of the $p 53$ variants might also be modulated by its downstream genes involved in the intrinsic pathway. To the best of our knowledge, this is the first multigene genotype-phenotype correlation analysis in relation to the apoptotic pathways in primary lymphocytes at a population level.

Because there is tissue specificity in response to carcinogen exposure, it would be ideal to compare the BPDEinduced $\mathrm{AC}$ measurements among different tissues of the same person. However, few reported studies have addressed this tissue specificity, nor did our study have such an opportunity. It was reported that $\mathrm{B}[\mathrm{a}] \mathrm{P}$-induced apoptosis of murine Hepa1c1c7 cells was through CASP-9 activation related with p53 accumulation and activation [8] and that a decrease in the expression of $\mathrm{Bcl}-2$ to $\mathrm{Bax}$ ratio was another hallmark of the process $[8,34]$. Although obtained from different cell types, these findings are consistent with our current observations that genetic variants in the genes involved in the intrinsic apoptotic pathway may play an important role in the prediction of AC phenotype. The Bcl-2 family is a group of evolutionarily conserved pro- and antiapoptotic proteins that play a pivotal role in the regulation of the mitochondrial-mediated (intrinsic) apoptotic pathway [35]. Bcl-2 inhibits apoptosis through heterodimerization with proapoptotic members of the Bcl-2 family, such as Bax and also through formation of channels that stabilize the mitochondrial membrane [36]. Bcl-2 expression has also been implicated in the pathogenesis of cancers [37, 38 ], and the expression of $\mathrm{Bcl}-2$ to Bax ratio seems to be important in determining both in vitro and in vivo response to chemotherapeutic drugs [39]. Recently, variant allele of $\mathrm{Bcl}-2-938 \mathrm{C}>\mathrm{A}$ was found to be associated with reduced prostate cancer risk in Caucasians in a small casecontrol study, possibly due to the elimination of an Sp1 binding site, a downregulation of Bcl-2 mRNA transcript levels, and unregulated programmed cell death [40], which is consistent with what we found in the current study (the variant A allele carriers were associated with high-AC phenotype that may help eliminating possible malignant cells).

Our results on the $p 53$ polymorphisms were not consistent with published data. For example, the wild-type $72 \mathrm{R}$ 
TABLE 2: Comparisons of mean BPDE-induced apoptosis capacity in apparently normal primary lymphocytes by the genotypes of selected apoptotic genes.

\begin{tabular}{|c|c|c|c|c|}
\hline Variable & No. $(\%)$ & $\mathrm{AC}($ mean $\pm \mathrm{SD})$ & $P$ value $^{(\mathrm{a})}$ & $P$ value $^{(\mathrm{b})}$ \\
\hline \multicolumn{5}{|l|}{ Intrinsic pathway } \\
\hline \multicolumn{5}{|l|}{$p 53 \mathrm{R} 72 \mathrm{P}$} \\
\hline RR & $91(53.5)$ & $180.47 \pm 164.13$ & Ref. & \\
\hline $\mathrm{RP}$ & $65(38.2)$ & $223.07 \pm 196.22$ & .143 & \\
\hline $\mathrm{PP}$ & $14(8.2)$ & $313.40 \pm 243.25$ & .067 & .016 \\
\hline \multicolumn{5}{|l|}{ p53 intron 3} \\
\hline 16-bpdel/del & $134(78.8)$ & $204.22 \pm 183.21$ & Ref. & \\
\hline 16-bpdel/ins & $34(20.0)$ & $204.51 \pm 194.62$ & .993 & \\
\hline 16-bpins/ins & $2(1.2)$ & $496.07 \pm 121.26$ & .027 & .274 \\
\hline \multicolumn{5}{|l|}{ p53 intron 6} \\
\hline GG & $135(79.4)$ & $199.44 \pm 179.10$ & Ref. & \\
\hline GA & $33(19.4)$ & $224.07 \pm 209.17$ & 0.495 & \\
\hline $\mathrm{AA}$ & $2(1.2)$ & $496.07 \pm 121.26$ & .021 & .099 \\
\hline \multicolumn{5}{|l|}{$B c l-2-938 C>A$} \\
\hline CC & $53(31.2)$ & $164.06 \pm 154.89$ & Ref. & \\
\hline CA & $76(44.7)$ & $216.62 \pm 180.38$ & .087 & \\
\hline $\mathrm{AA}$ & $41(24.1)$ & $247.62 \pm 225.67$ & .046 & .037 \\
\hline \multicolumn{5}{|l|}{$B A X-248 \mathrm{G}>\mathrm{A}$} \\
\hline GG & $144(84.7)$ & $205.39 \pm 189.73$ & Ref. & \\
\hline GA & $25(14.7)$ & $225.99 \pm 173.85$ & .613 & \\
\hline $\mathrm{AA}$ & $1(0.6)$ & 84.85 & - & \\
\hline \multicolumn{5}{|l|}{ CASP9 Q221R } \\
\hline QQ & $53(31.2)$ & $194.75 \pm 169.29$ & Ref. & \\
\hline QR & $75(44.1)$ & $213.91 \pm 199.95$ & .571 & \\
\hline $\mathrm{RR}$ & $42(24.7)$ & $213.00 \pm 187.11$ & .620 & .704 \\
\hline \multicolumn{5}{|c|}{ Extrinsic pathway } \\
\hline \multicolumn{5}{|l|}{ DR4 T209R } \\
\hline $\mathrm{TT}$ & $52(30.6)$ & $179.61 \pm 179.86$ & Ref. & \\
\hline $\mathrm{TR}$ & $75(44.1)$ & $229.67 \pm 206.45$ & .160 & \\
\hline $\mathrm{RR}$ & $43(25.3)$ & $203.39 \pm 155.49$ & .497 & .485 \\
\hline \multicolumn{5}{|l|}{ Fas $-1377 \mathrm{G}>\mathrm{A}$} \\
\hline GG & $126(74.1)$ & $218.66 \pm 195.82$ & Ref. & \\
\hline GA & $42(24.7)$ & $179.99 \pm 158.13$ & .248 & \\
\hline $\mathrm{AA}$ & $2(1.2)$ & $100.14 \pm 92.38$ & .396 & .182 \\
\hline \multicolumn{5}{|l|}{ Fas $-670 \mathrm{~A}>\mathrm{G}$} \\
\hline $\mathrm{AA}$ & $43(25.3)$ & $210.82 \pm 173.91$ & Ref. & \\
\hline GA & $86(50.6)$ & $236.97 \pm 203.18$ & .472 & \\
\hline GG & $41(24.1)$ & $143.07 \pm 147.70$ & .058 & .085 \\
\hline \multicolumn{5}{|l|}{ FasL $-844 \mathrm{~T}>\mathrm{C}$} \\
\hline CC & $79(46.5)$ & $225.68 \pm 195.41$ & Ref. & \\
\hline CT & $74(43.5)$ & $190.11 \pm 180.80$ & .245 & \\
\hline $\mathrm{TT}$ & $17(10.0)$ & $200.82 \pm 173.81$ & .629 & .464 \\
\hline \multicolumn{5}{|l|}{ CASP8 D302H } \\
\hline DD & $127(74.7)$ & $202.30 \pm 184.45$ & Ref. & \\
\hline $\mathrm{DH}$ & $38(22.4)$ & $210.97 \pm 195.10$ & .802 & \\
\hline $\mathrm{HH}$ & $5(2.9)$ & $320.41 \pm 183.38$ & .162 & .389 \\
\hline \multicolumn{5}{|l|}{ CASP10 I522L } \\
\hline II & $54(31.8)$ & $239.07 \pm 205.18$ & Ref. & \\
\hline IL & $74(43.5)$ & $212.19 \pm 177.84$ & .430 & \\
\hline LL & $42(24.7)$ & $159.49 \pm 171.44$ & .046 & .046 \\
\hline
\end{tabular}


TABle 2: Continued.

\begin{tabular}{|c|c|c|c|c|}
\hline Variable & No. (\%) & $\mathrm{AC}($ mean $\pm \mathrm{SD})$ & $P$ value $^{(\mathrm{a})}$ & $P$ value $^{(\mathrm{b})}$ \\
\hline \multicolumn{5}{|c|}{ Effective CASPs } \\
\hline \multicolumn{5}{|c|}{$C A S P 3-1337 \mathrm{C}>\mathrm{G}$} \\
\hline CC & $107(62.9)$ & $210.98 \pm 202.46$ & Ref. & \\
\hline CG & $51(30.0)$ & $212.23 \pm 166.75$ & .970 & \\
\hline GG & $12(7.1)$ & $159.34 \pm 109.53$ & .388 & .516 \\
\hline \multicolumn{5}{|c|}{ CASP7 D255E } \\
\hline DD & $95(55.9)$ & $214.49 \pm 190.29$ & Ref. & \\
\hline $\mathrm{DE}$ & $68(40.0)$ & $195.79 \pm 166.92$ & .516 & \\
\hline $\mathrm{EE}$ & $7(4.1)$ & $231.51 \pm 318.48$ & .829 & .801 \\
\hline
\end{tabular}

(a) Two-sided Student $t$-test.

(b) Trend test obtained from general linear regress model with adjustment for age and sex.

TABLE 3: Comparisons of mean BPDE-induced apoptosis capacity in apparently normal primary lymphocytes by $p 53$ diplotypes.

\begin{tabular}{ccccc}
\hline$p 53$ diplotypes & No. $(\%)$ & AC $($ mean \pm SD $)$ & $P$ value $^{(\mathrm{a})}$ & $P$ value \\
\hline R-del-G & & & & \\
2 copies & $81(47.6)$ & $177.57 \pm 159.94$ & Ref. & \\
1 copy & $74(43.5)$ & $220.39 \pm 197.21$ & .138 & \\
0 copy & $15(8.8)$ & $307.90 \pm 235.37$ & .009 & .016 \\
R-ins-G & & & & \\
0 copy & $116(68.2)$ & $190.05 \pm 174.57$ & Ref. & \\
1 copy & $49(28.8)$ & $238.99 \pm 197.24$ & .116 & \\
2 copies & $5(2.9)$ & $310.86 \pm 311.47$ & .146 & .094 \\
P-ins-A & & & & \\
0 copy & $143(84.1)$ & $202.33 \pm 179.92$ & Ref. & \\
1 copy & $25(14.7)$ & $215.43 \pm 215.45$ & .745 & \\
2 copies & $2(1.2)$ & $496.07 \pm 121.26$ & .023 & .154 \\
\hline
\end{tabular}

(a) Two-sided Student $t$-test.

(b) Trend test obtained from general linear regress model with adjustment for age and sex.

allele was found to be associated with an increased ability to induce apoptosis in response to radiation or cytotoxic drugs $[18,41,42]$. However, other data suggested that the $72 \mathrm{P}$ allele had a stronger transcription effect in response to DNA damage, leading to enhanced apoptotic phenotype [43]. These previous studies were mainly based on assays with cell lines $[18,41]$ and suffered with a limited sample size $[18,41,42]$. Most importantly, no previous study took into account other coexisting polymorphisms in the genes involved in the intrinsic pathway, which may play an important role in the $\mathrm{B}[\mathrm{a}] \mathrm{P}$-induced apoptosis [8]. In the present study with apparently normal primary lymphocytes, we found that all minor variant alleles of the three $p 53$ polymorphisms were associated with a higher AC phenotype and that the overall effects on the AC phenotype appeared to be affected by the CASP9 Q221R polymorphism, but the interaction between polymorphisms of $p 53$ and CASP9 was only borderline significant due to a limited study power. However, our findings of this intrinsic apoptotic pathway in lymphocytes may be relevant to other types of tissue as well because this kind of induced apoptosis in lymphocytes may be inheritable [44]. Thus these results, although preliminary, need to be substantiated in larger studies.

Previous finding on the CASP10 I522L polymorphism from a large breast cancer study showed that the variant LL genotype was associated with a borderline significant 1.30-fold increased cancer risk compared with the wild-type II homozygote [21], which is consistent with the notion that the LL homozygote contributes to a diminished AC. However, the role of the extrinsic pathway (or only CASP10) in $\mathrm{B}[\mathrm{a}] \mathrm{P}$-induced apoptosis was not obvious in the present study, which needs further evaluation.

In conclusion, this proof-of-principle study of genotypephenotype correlation provides evidence that potentially functional polymorphisms in the core genes of the apoptotic pathways may have a role in regulating the apoptotic response to carcinogen exposure, at least in primary lymphocytes, although there is tissue specificity in response to exposure to carcinogens. Such a modification of host carcinogen-induced AC in primary lymphocytes may contribute to variation in individual susceptibility to cancer in the general population. Although this study may be limited due to small sample size, multiple tests, and lack of repeated AC measurements for the same individuals, the findings, if validated in more rigorously designed and larger studies, should facilitate the design of future studies aimed at identifying subpopulations at risk of cancer and other apoptosis-related diseases.

\section{ACKNOWLEDGMENTS}

The authors would like to thank Margaret Lung, Kathryn Patterson, and Leanel Fairly for their assistance in recruiting the subjects; Luo Wang, Zhensheng Liu, and Yawei Qiao for technical assistance; Kristina R. Dahlstrom, Jianzhong $\mathrm{He}$, and Kejin $\mathrm{Xu}$ for their laboratory assistance; Monica Domingue for manuscript preparation; and Christine F. Wogan for scientific editing. This study was supported in part by National Institutes of Health Grants nos. R01 ES11740 and CA100264 to Q. W. and nos. P30 CA16672 and U01 ES11047 to The University of Texas M. D. Anderson Cancer Center. 


\section{REFERENCES}

[1] C. B. Thompson, "Apoptosis in the pathogenesis and treatment of disease," Science, vol. 267, no. 5203, pp. 1456-1462, 1995.

[2] G. I. Evan and K. H. Vousden, "Proliferation, cell cycle and apoptosis in cancer," Nature, vol. 411, no. 6835, pp. 342-348, 2001.

[3] S. W. Lowe and A. W. Lin, "Apoptosis in cancer," Carcinogenesis, vol. 21, no. 3, pp. 485-495, 2000.

[4] I. M. Ghobrial, T. E. Witzig, and A. A. Adjei, "Targeting apoptosis pathways in cancer therapy," CA-A Cancer Journal for Clinicians, vol. 55, no. 3, pp. 178-194, 2005.

[5] D. H. Phillips, "Fifty years of benzo(a)pyrene," Nature, vol. 303, no. 5917, pp. 468-472, 1983.

[6] H. V. Gelboin, "Benzo[alpha]pyrene metabolism, activation and carcinogenesis: role and regulation of mixed-function oxidases and related enzymes," Physiological Reviews, vol. 60, no. 4, pp. 1107-1166, 1980.

[7] M. C. MacLeod and M. Tang, "Interactions of benzo(a)pyrene diol-epoxides with linear and supercoiled DNA," Cancer Research, vol. 45, no. 1, pp. 51-56, 1985.

[8] C.-B. Ko, S.-J. Kim, C. Park, et al., "Benzo(a)pyrene-induced apoptotic death of mouse hepatoma Hepalclc7 cells via activation of intrinsic caspase cascade and mitochondrial dysfunction," Toxicology, vol. 199, no. 1, pp. 35-46, 2004.

[9] W. Lei, R. Yu, S. Mandlekar, and A.-N. T. Kong, "Induction of apoptosis and activation of interleukin $1 \beta$-converting enzyme/ced-3 protease (caspase-3) and c-Jun $\mathrm{NH}_{2}$-terminal kinase 1 by benzo(a)pyrene," Cancer Research, vol. 58, no. 10, pp. 2102-2106, 1998.

[10] M. Ramet, K. Castren, K. Jarvinen, et al., " $\mathrm{p}^{53}$ Protein expression is correlated with benzo $[a]$ pyrene-DNA adducts in carcinoma cell lines," Carcinogenesis, vol. 16, no. 9, pp. 21172124, 1995.

[11] T. Miyashita and J. C. Reed, "Tumor suppressor $\mathrm{p}^{53}$ is a direct transcriptional activator of the human bax gene," Cell, vol. 80, no. 2, pp. 293-299, 1995.

[12] M. Bennett, K. Macdonald, S.-W. Chan, J. P. Luzio, R. Simari, and P. Weissberg, "Cell surface trafficking of Fas: a rapid mechanism of $\mathrm{p}^{53}$-mediated apoptosis," Science, vol. 282, no. 5387, pp. 290-293, 1998.

[13] M. S. Sheikh, T. F. Burns, Y. Huang, et al., " $\mathrm{p}^{53}$-dependent and -independent regulation of the death receptor KILLER/DR5 gene expression in response to genotoxic stress and tumor necrosis factor $\alpha$, Cancer Research, vol. 58, no. 8, pp. 1593$1598,1998$.

[14] D. R. Green and G. Kroemer, "The pathophysiology of mitochondrial cell death," Science, vol. 305, no. 5684, pp. 626629, 2004.

[15] A. Ashkenazi and V. M. Dixit, "Death receptors: signaling and modulation,” Science, vol. 281, no. 5381, pp. 1305-1308, 1998.

[16] S. W. Lowe, E. Cepero, and G. Evan, "Intrinsic tumour suppression," Nature, vol. 432, no. 7015, pp. 307-315, 2004.

[17] Q. Wei, L. Cheng, C. I. Amos, et al., "Repair of tobacco carcinogen-induced DNA adducts and lung cancer risk: a molecular epidemiologic study," Journal of the National Cancer Institute, vol. 92, no. 21, pp. 1764-1772, 2000.

[18] X. Wu, H. Zhao, C. I. Amos, et al., " $\mathrm{p}^{53}$ Genotypes and haplotypes associated with lung cancer susceptibility and ethnicity," Journal of the National Cancer Institute, vol. 94, no. 9, pp. 681-690, 2002.

[19] B. L. Park, L. H. Kim, H. S. Cheong, et al., "Identification of variants in cyclin D1 (CCND1) and B-cell CLL/lymphoma 2
(BCL2)," Journal of Human Genetics, vol. 49, no. 8, pp. 449$454,2004$.

[20] A. Saxena, O. Moshynska, K. Sankaran, S. Viswanathan, and D. P. Sheridan, "Association of a novel single nucleotide polymorphism, G(-248)A, in the $5^{\prime}$-UTR of BAX gene in chronic lymphocytic leukemia with disease progression and treatment resistance," Cancer Letters, vol. 187, no. 1-2, pp. 199-205, 2002.

[21] G. MacPherson, C. S. Healey, M. D. Teare, et al., "Association of a common variant of the CASP8 gene with reduced risk of breast cancer," Journal of the National Cancer Institute, vol. 96, no. 24, pp. 1866-1869, 2004.

[22] A. Hirano, H. Nagai, H. Harada, S. Haga, T. Kajiwara, and M. Emi, "Two novel single-nucleotide polymorphisms of the Caspase-9 (CASP9) gene in the Japanese population," Genes and Immunity, vol. 2, no. 2, pp. 117-118, 2001.

[23] M. J. Fisher, A. K. Virmani, L. Wu, et al., "Nucleotide substitution in the ectodomain of TRAIL receptor DR4 is associated with lung cancer and head and neck cancer," Clinical Cancer Research, vol. 7, no. 6, pp. 1688-1697, 2001.

[24] Q. R. Huang, D. Morris, and N. Manolios, "Identification and characterisation of polymorphisms in the promoter region of the human Apo-1/Fas (CD95) gene," Molecular Immunology, vol. 34, no. 8-9, pp. 577-582, 1997.

[25] J. Wu, C. Metz, X. Xu, et al., "A novel polymorphic CAAT/enhancer-binding protein $\beta$ element in the FasL gene promoter alters Fas ligand expression: a candidate background gene in African American systemic lupus erythematosus patients," Journal of Immunology, vol. 170, no. 1, pp. 132-138, 2003.

[26] S. Kanemitsu, K. Ihara, A. Saifddin, et al., "A functional polymorphism in Fas (CD95/APO-1) gene promoter associated with systemic lupus erythematosus," Journal of Rheumatology, vol. 29, no. 6, pp. 1183-1188, 2002.

[27] H. Shen, Y. Zheng, E. M. Sturgis, M. R. Spitz, and Q. Wei, " $p^{53}$ codon 72 polymorphism and risk of squamous cell carcinoma of the head and neck: a case-control study," Cancer Letters, vol. 183, no. 2, pp. 123-130, 2002.

[28] A. Hazra, R. M. Chamberlain, H. B. Grossman, Y. Zhu, M. R. Spitz, and X. Wu, "Death receptor 4 and bladder cancer risk," Cancer Research, vol. 63, no. 6, pp. 1157-1159, 2003.

[29] T. Sun, X. Miao, X. Zhang, W. Tan, P. Xiong, and D. Lin, "Polymorphisms of death pathway genes FAS and FASL in esophageal squamous-cell carcinoma," Journal of the National Cancer Institute, vol. 96, no. 13, pp. 1030-1036, 2004.

[30] B. J. Stuck, M. A. Pani, F. Besrour, et al., "Fas ligand gene polymorphisms are not associated with Hashimoto's thyroiditis and Graves' disease," Human Immunology, vol. 64, no. 2, pp. 285-289, 2003.

[31] X. Ke, A. Collins, and S. Ye, "PIRA PCR designer for restriction analysis of single nucleotide polymorphisms," Bioinformatics, vol. 17, no. 9, pp. 838-839, 2001.

[32] L.-E. Wang, L. Cheng, M. R. Spitz, and Q. Wei, "Fas A670G polymorphism, apoptotic capacity in lymphocyte cultures, and risk of lung cancer," Lung Cancer, vol. 42, no. 1, pp. 1-8, 2003.

[33] M. Stephens and P. Donnelly, "A comparison of Bayesian methods for Haplotype reconstruction from population Genotype data," American Journal of Human Genetics, vol. 73, no. 5, pp. 1162-1169, 2003.

[34] V. M. Salas and S. W. Burchiel, "Apoptosis in Daudi human B cells in response to benzo[a]pyrene and benzo[a]pyrene-7,8dihydrodiol," Toxicology and Applied Pharmacology, vol. 151, no. 2, pp. 367-376, 1998. 
[35] S. J. Korsmeyer, "Regulators of cell death," Trends in Genetics, vol. 11, no. 3, pp. 101-105, 1995.

[36] J. C. Reed, "Bcl-2 and the regulation of programmed cell death," Journal of Cell Biology, vol. 124, no. 1-2, pp. 1-6, 1994.

[37] Q.-L. Lu, P. Abel, C. S. Foster, and E.-N. Lalani, "bcl-2: role in epithelial differentiation and oncogenesis," Human Pathology, vol. 27, no. 2, pp. 102-110, 1996.

[38] L. Kaklamanis, A. Savage, N. Mortensen, et al., "Early expression of bcl-2 protein in the adenoma-carcinoma sequence of colorectal neoplasia," Journal of Pathology, vol. 179, no. 1, pp. 10-14, 1996.

[39] J. C. Reed, "Bcl-2 family proteins: regulators of apoptosis and chemoresistance in hematologic malignancies," Seminars in Hematology, vol. 34, no. 4, supplement 5, pp. 9-19, 1997.

[40] L. R. Kidd, A. Coulibaly, T. M. Templeton, et al., "Germline BCL-2 sequence variants and inherited predisposition to prostate cancer," Prostate Cancer and Prostatic Diseases, vol. 9, no. 3, pp. 284-292, 2006.

[41] P. Dumont, J. I.-J. Leu, A. C. Della Pietra III, D. L. George, and M. Murphy, "The codon 72 polymorphic variants of $\mathrm{p}^{53}$ have markedly different apoptotic potential," Nature Genetics, vol. 33, no. 3, pp. 357-365, 2003.

[42] A. Osorio, B. Martínez-Delgado, M. Pollán, et al., "A haplotype containing the $\mathrm{p}^{53}$ polymorphisms Ins16bp and Arg72Pro modifies cancer risk in BRCA2 mutation carriers," Human Mutation, vol. 27, no. 3, pp. 242-248, 2006.

[43] M. Thomas, A. Kalita, S. Labrecque, D. Pim, L. Banks, and G. Matlashewski, "Two polymorphic variants of wild-type $\mathrm{p}^{53}$ differ biochemically and biologically," Molecular and Cellular Biology, vol. 19, no. 2, pp. 1092-1100, 1999.

[44] A. Schmitz, J. Bayer, N. Dechamps, L. Goldin, and G. Thomas, "Heritability of susceptibility to ionizing radiationinduced apoptosis of human lymphocyte subpopulations," International Journal of Radiation Oncology Biology Physics, vol. 68, no. 4, pp. 1169-1177, 2007. 


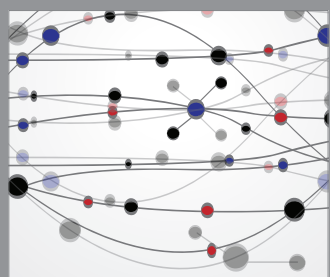

The Scientific World Journal
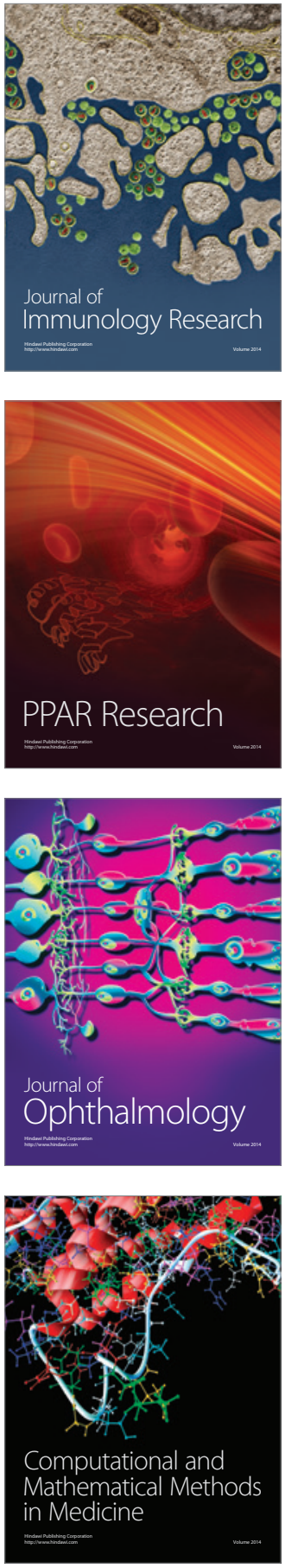

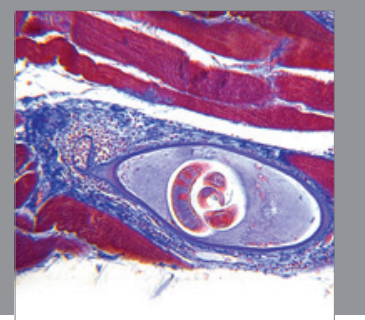

Gastroenterology

Research and Practice
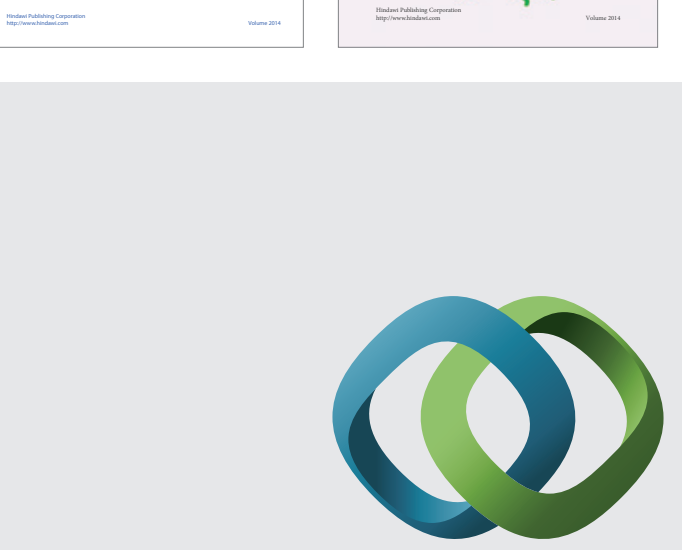

\section{Hindawi}

Submit your manuscripts at

http://www.hindawi.com
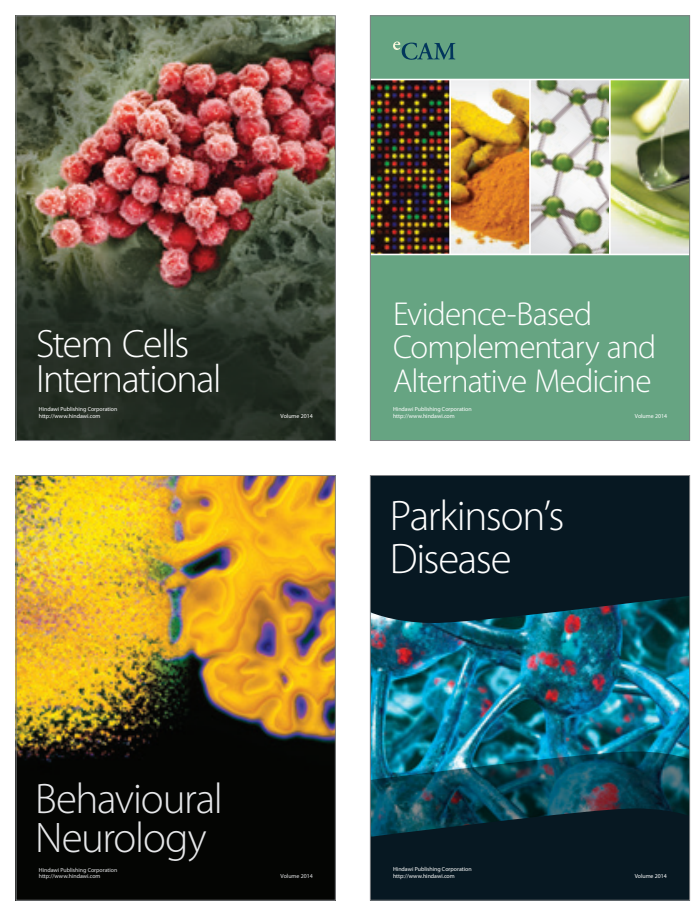

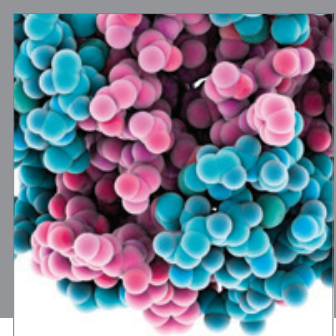

Journal of
Diabetes Research

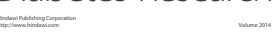

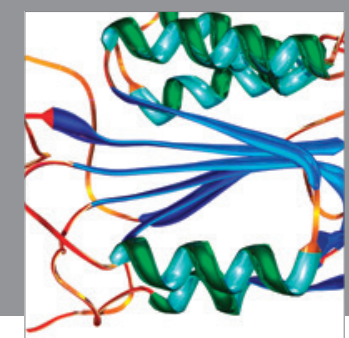

Disease Markers
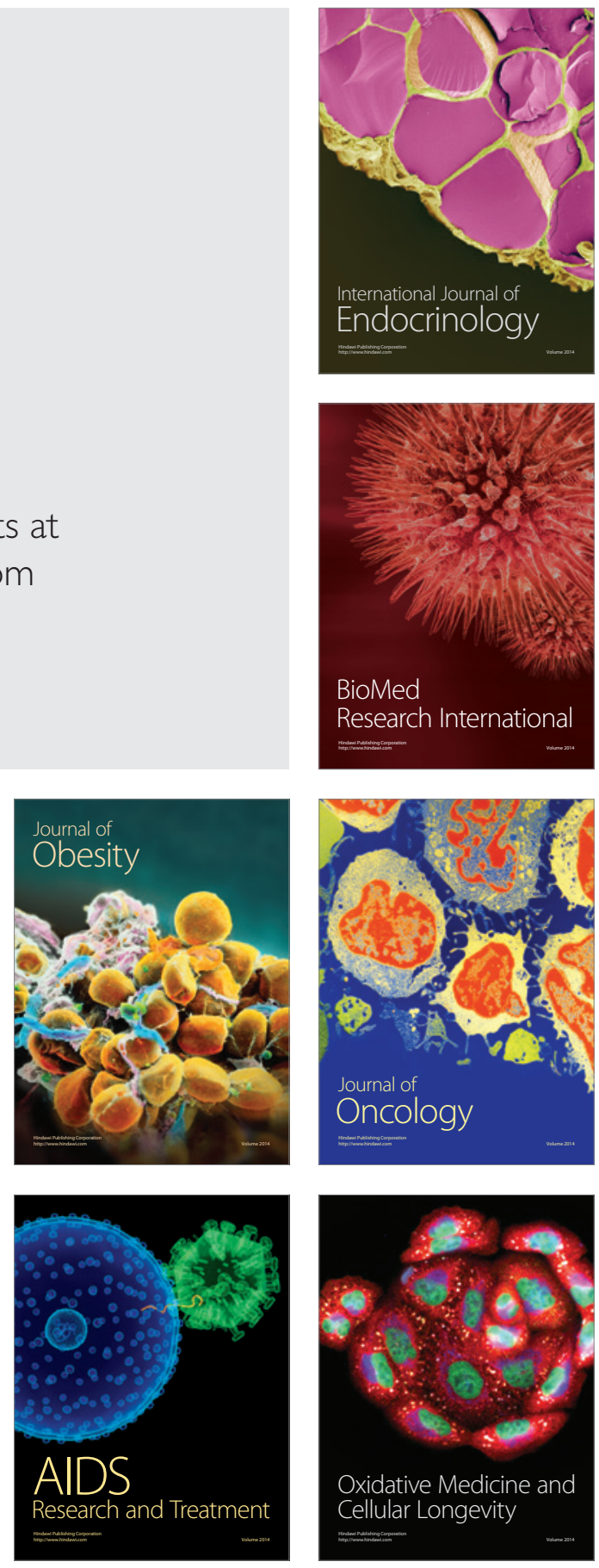